\title{
An Empirical Capital Market Rate Function for an Emerging Market Economy in International Financial Crisis
}

\section{Chris Harmse and Charlotte Du Toit}

\section{Department of Economics, University of Pretoria}

\section{ABSTRACT}

After the first democratic election in South Africa in April 1994, South Africa's financial markets became more exposed and vulnerable to international developments, vide the financial crisis of 1998 . This vulnerability raises some important questions. Has its greater degree of openness led to a structural change in the South African economy? Are long-term interest rates now primarily determined by international sentiment regardless of domestic economic and political conditions, during periods of international financial market volatility? And, in the event, what is the consequent effect on monetary policy in South Africa? The aim of this paper is to investigate these questions by using a cointegration approach to estimate a long-run interest or bond rate function for South Africa.

JEL F 40

\section{INTRODUCTION}

Prior to the democratic election of 1994, the South African capital market was known as a captive market. Domestic private and government institutions dominated transactions on financial markets. Monetary policy was conducted in an isolated environment, where monetary targets and the fixing of short-term interest rates were used as the main policy instruments in the attempt to achieve price and exchange rate stability.

After the election, the abolition of sanctions and the end of disinvestment in South Africa, together with the scrapping of exchange controls applicable to foreigners, South Africa's financial markets became more exposed to world financial market movements. The East Asian and Russian crises of 1998 exposed the new-found vulnerability of South African financial markets. This vulnerability raises the following important questions: Has its greater degree of openness led to a structural change in the South African economy? Are longterm interest rates now primarily determined by international sentiment, regardless of domestic economic and political conditions, during periods of 
international financial volatility? And, if so, what is the consequent effect on monetary policy in South Africa? The aim of this paper is to investigate these questions.

The sample period covers a twelve-month time span, the year 1998, during which South Africa experienced severe turmoil in domestic financial markets. The aim of the research was to determine the longer-run trend in capital market rates at internationally volatile times, rather than to develop a tool for analyzing day-to-day trading. A market-related approach was followed, where the effects of changes in money, foreign exchange and foreign financial markets on the South African capital market were modelled. These results are not necessarily applicable during times of stability in international financial market sentiment, and need to be addressed in further research. A cointegration approach was used to estimate a long-run interest or bond rate function for South Africa. The estimation consists of a long-run equilibrium function, representing the long-run equilibrium growth path of long-term interest rates and an error correction model (ECM), representing the short-run dynamic adjustment process to longrun equilibrium.

Apart from analyzing the univariate characteristics of the data and determining the long-run cointegration and short-run dynamic relationships, the estimated function is subjected to rigorous diagnostic and stability testing.

\section{CHANGES IN SOUTH AFRICAN FINANCIAL MARKETS SINCE 1994}

The changeover of the South African political system to a democratic dispensation with the country's first non-racial election on 27 April 1994 removed the political barriers that had prevented successful economic adjustment during the 1980s. The dropping of sanctions and disinvestment actions against South Africa opened up its markets to foreign goods, services and financial flows. During 1995 alone, more than R21 billion worth of foreign capital flowed into the economy (QB, June 1996). The initial political stability, a decreasing rate of inflation, record harvests, high real interest rates and a stable exchange rate, all served to attract foreign capital, although mainly of volatile, indirect and speculative nature. The real economic growth rate increased from 1.3 per cent in 1993 to 2.75 per cent in 1994, 3.3 per cent in 1995 and was 3.2 per cent in 1996 (QB, June 1998: S41).

However, uncertain political events combined with persistently high crime levels and unrest since the beginning of 1996, again led to quick withdrawal of foreign capital. The result was a serious depreciation of the rand, together with uncertainty and instability in capital and equity (share) markets. Capital market rates 
increased rapidly by more than 300 basis points, from the middle of February to the middle of April 1996 (www.sharenet.co.za).

Monetary policy aimed at curbing inflation and easing the balance of payments constraint, tax reform and fiscal discipline, all came suddenly under pressure after the middle of 1997, as attempts were made to open the economy to international competition and secure access to new markets.

Foreign market sentiment towards South Africa started to influence daily movements on the financial markets, and was reflected in movements on the equity, capital and foreign exchange markets. These movements, especially since the middle of 1997 , were in conflict with the improved macroeconomic fundamentals of the South African economy: "South Africa - where macroeconomic stability is not in doubt and the financial system is fundamentally sound - could not escape the spillover effects of the Asian crisis" (QB, December 1998: 1). Whereas capital market rates had been determined mostly by domestic demand and supply of shares and bonds prior to the 1994 election, global financial markets and international market sentiment started to dominate movements in capital market rates after 1994. The yield curve tumed negative as capital market rates started to lead interest rate movements, rather than following short-run money market rates. The vulnerability and instability thus generated were especially conspicuous over the 1998 sample period, when heavy speculative selling against the rand of fixed-interest securities to the value of $\$ 4$ billion between April and August 1998 by non-resident portfolio investors, caused a sharp rise in bank lending rates by 725 basis points. The volatility was heightened by the dramatic recovery of the market from the end of August to October during the same year (QB, December 1998: 1).

\section{THE SOUTH AFRICAN CAPITAL MARKET}

The capital market in South Africa represents the long-term part of the financial system. The market acts as a source of funds with maturity dates longer than three years (Fourie, Falkena and Kok, 1992: 130). The market is a complex entity, which consists of institutions and mechanisms through which funds are pooled and made available to the private and the public sectors of the economy.

The secondary market, where previously issued securities (fixed-interest and equities) are traded, makes up the largest part of the market, about 96 per cent (QB, June 1998). The primary market, which makes up the rest of the market, is where first issues are offered to the public. The fixed-interest securities market, where mainly government bonds are traded, forms the largest part of the secondary market. Bond transactions to the value of $\$ 4268.822$ billion on the 
Johannesburg Bond Exchange took place in 1997. This was 99 per cent of the turnover in the market as a whole during 1997 (QB, March 1999: S30).

Government stocks are sold by means of a tap issue, or on tender basis. In the case of a tap issue the Reserve Bank (central bank) buys the stock from the Treasury at a rate at which the Bank can sell a fairly large volume in the market. By selling the biggest volume at the highest price (lowest interest rate) the Reserve Bank aims to find a balance between demand and supply. New stock is issued by means of an announcement to the market on the general terms of the issue, which includes the coupon, maturity date and maximum stock to be issued. The yield rate is determined by negotiations between buyers and the issuer (Fourie, Falkena and Kok, 1992: 133).

The leading bond on the South African capital market is the R150, 12 per cent 2005 government bond. Daily buying and selling determine the yield rate of the bond, which can be higher or lower than its 12 per cent value, payable on the date of redemption. The R150 yield rate can be considered the most important capital market rate, and it influences all other bond rates. Therefore, an empirical function has been estimated for the R150 yield rate.

\section{THE EMPIRICAL MODEL: R150}

The model is estimated on a daily ( 5 days per week) basis over the period $05 / 01 / 1998$ to $11 / 12 / 1998$. The sample period is of great significance since South Africa experienced a large degree of volatility (prosperity and economic crisis) in the capital market during 1998 (Figure 1).

Data have been obtained from various sources ${ }^{1}$ and consist of the daily closing figures for the relevant variables.

Although numerous explanatory variables were tested for their significance in explaining the volatile behavior of the $\mathrm{R} 150$, the following variables were ultimately included in the model: the rand/dollar exchange rate; the overall share price index on the Johannesburg Stock Exchange; the Dow Jones Stock Exchange Industrial index; the rand/pound exchange rate; the US thirty-year bond rate, which is considered to be the leading international capital market rate; net purchases of South African bonds by foreigners; the repo rate as a short-run interest rate and cost of financial assistance to the money market. 


\section{Figure $1 \quad$ R150 yield rate, 1998}

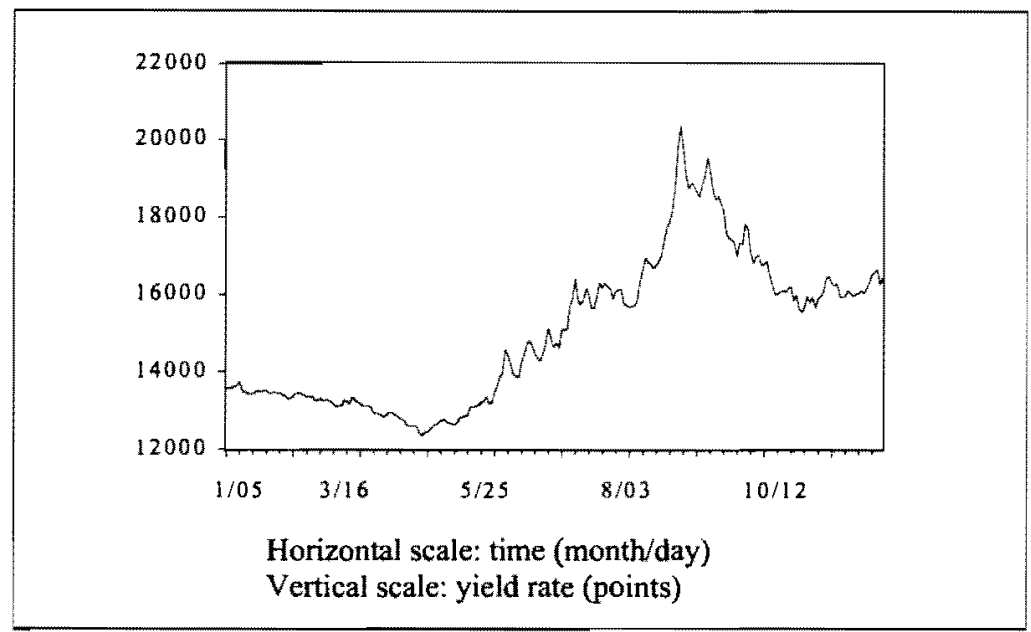

In order to avoid bias in estimation by ignoring some significant events in the South African economy, a number of dummy variables were created and tested to describe the short-run effects of the following events: international (exogenous) economic and political events (e.g. the East Asian and Russian crises) and the announcement of domestic macroeconomic data such as monthly merchandise exportimport trade, monthly level of foreign reserves, monthly consumer and production price indices and monthly $\mathrm{M} 3$ and credit figures.

The dummies were created by activating the days on which the announcements took place. However, the whole issue is far more complex since the market usually responds in two ways. First, prior to the release of economic data the market discounts the expected values, whether negative or positive. Second, the market responds to deviations between the expected and actual values of the monthly merchandise exportimport trade, monthly level of foreign reserves, monthly consumer and production price indices and monthly $\mathrm{M} 3$ and credit figures. If there is no deviation the market usually does not respond.

The estimated model has certain constraints with regard to expectations. The first is the lack of a historically and scientifically reliable time series of the expected values, usually released by Reuters. Second, also due to the lack of data on expected values, the effect of deviations in the explanatory variables could not be tested. For these reasons, certain a priori economically significant variables turned out to be statistically insignificant and had to be dropped from the model (e.g. the CPI and PPI figures). 
In analyzing the univariate characteristics of the data, the Dickey-Fuller (DF) and Augmented Dickey-Fuller (ADF) tests were used to establish the order of integration of the data series. A list of the variables is given in Appendix 1. Results (tables A1 and A2) together with a description of the testing procedure are given in Appendix 2. In addition, graphing the data series in levels as well as their first and second differences, looking at correlograms or autocorrelation functions and spectrum analysis, proved to be helpful when ADF-test results were inconclusive.

\subsection{Estimation results}

The estimation technique used was the Engle and Yoo (1989) three-step procedure, which is an extension of the Engle-Granger (1987) two-step procedure. This approach consists of a simple test for the presence of cointegration between variables, indicating whether a particular set of variables represents a combination that is consistent with a long-run equilibrium relationship. (See Appendix 2.)

At the second stage an ECM was constructed in order to estimate the short-run or dynamic adjustment process to long-run equilibrium. The ECM indicates the dynamic relationship between variables, i.e. fluctuations in the dependent variable around its long-run trend are explained by fluctuations in the explanatory variables around their long-term trends. "The idea is simply that a proportion of the disequilibrium from one period is corrected in the next" (Engle and Granger, 1987: 254). Long-term effects are accounted for by the inclusion of the error term (e) of the long-term cointegration relationship in the ECM (Harris, 1995: 24).

All the variables in an ECM were transformed (differenced) into stationary variables. A regression of the stationary form of the dependent variable on the other stationary variables and the first lag of the error term of the cointegrating regression was run. Other variables besides those included in the cointegrating regression can be considered for inclusion in the ECM. Examples of such variables are those which were discarded from the cointegrating regression, stationary variables (in levels) and variables, which theoretically will only influence the short-run trend of the dependent variable and were therefore also not considered for inclusion in the cointegrating regression. Since all the variables in the ECM are stationary, the assumptions of classical regression analysis are fulfilled. Therefore, standard diagnostic tests can be used to determine which variables should be included in the final specification of the ECM (Harris, 1995: 24). 
The third step is applied to adjust the coefficients and $t$-statistics so that they are closer to their true values. This ensures that the variables included in the longnun regression can be evaluated statistically. Engle and Yoo (1989) have proposed a "third step" in addition to the Engle and Granger two-step estimation technique which is computationally tractable and overcomes two of the disadvantages of the two-step procedure.

This step provides a correction to the parameter estimates of the first stage, static regression that makes them asymptotically equivalent to FIML and provides a set of standard errors, which allows the valid calculation of standard $t$-tests.

The third step simply consists of a further regression of the conditioning variable from the static regression multiplied by minus the error correction parameter, regressed on the errors from the second-stage error correction model. The coefficients from this model are the corrections to the parameter estimates while their standard errors are the relevant standard errors for inference.

The three steps are then:

First estimate a standard cointegrating regression of the form:

$Y_{t}=\alpha^{\prime} X_{t}+Z_{t}$ where $Z_{t}$ is the OLS (ordinary least square) residual to give firststage estimates of $\alpha$.

Then estimate a second-stage dynamic model (ECM) using the residuals from the cointegrating regression to impose the long-run constraint: $\Delta Y_{t}=\Phi(L) \Delta Y_{t-1}+\Omega(L) \Delta X_{t}+\delta Z_{r-1}+\mu_{i}$

The third stage then consists of the regression: $\mu_{i}=\sigma\left(-\hat{\delta} X_{t}\right)+v_{t}$

The correction for the first-stage estimates is then simply: $\alpha^{3}=\alpha^{1}+\varepsilon$ and the correct standard errors for $\alpha^{3}$ are given by the standard errors for $\varepsilon$ ( $S E \partial$ in the third-stage regression.

The $t$-values for $\alpha^{3}$ are given by: $\quad t=\frac{\alpha^{3}}{S E_{\varepsilon}}$

The estimation results obtained for the $\mathrm{R} 150$ are reported below. The long-run relationship - the cointegration equation - is listed first, followed by the ECM together with the results from diagnostic tests performed on the ECM. The cointegration correction is finally shown for the long-run cointegration relationship. Figure 2 gives a graphical representation of the goodness-of-fit of the estimated R150-function. 
Long-run interest (yield) rate: $\mathbf{R} 1 \mathbf{S O}^{\mathbf{2}}$

Table 1 Cointegration equation: Dependent variable: $\ln \left(\mathbf{R}^{150} \mathbf{t}_{t}\right)$

\begin{tabular}{|c|c|c|c|}
\hline & Coefficient & s.e. & t-ratio \\
\hline In(rand_dollar, & 0.905596 & 0.019766 & 45.81651 \\
\hline $\ln \left(\right.$ jseover $\left._{i}\right)$ & -0.332431 & 0.011913 & -27.90526 \\
\hline constant & 2.642065 & 0.285303 & 9.260568 \\
\hline
\end{tabular}

E-G cointegration ${ }^{3} \quad-3.188$

Table 2 ECM: Dependent variable: $\Delta \ln \left(\mathrm{R}^{150_{t}}\right)$

\begin{tabular}{|c|c|c|c|}
\hline & Coefficient & s.e. & t-ratio \\
\hline resid $_{t-1}$ & -0.134124 & 0.025577 & -5.243858 \\
\hline$\Delta \ln ($ jseover $)$ & -0.221417 & 0.035425 & -6.250355 \\
\hline$\Delta \ln \left(\right.$ jseover $\left._{i+1}\right)$ & -0.121188 & 0.034265 & -3.536764 \\
\hline$\Delta \ln ($ rand_dollar $)$ & 0.514554 & 0.050723 & 10.14439 \\
\hline$\Delta \ln \left(\right.$ dow $\left._{t+1}\right)$ & 0.114825 & 0.045944 & 2.499229 \\
\hline$\Delta \ln \left(\right.$ dow $\left._{t-2}\right)$ & 0.100531 & 0.044457 & 2.261312 \\
\hline$\Delta \ln \left(\right.$ pound $\left._{\mathrm{t}-1}\right)$ & 0.093540 & 0.037900 & 2.468081 \\
\hline$\Delta \ln$ (ustbond $30_{t-1}$ ) & 0.162747 & 0.063504 & 2.562800 \\
\hline dum_foreign $n_{\mathfrak{r}}$ & 0.007938 & 0.001628 & 4.875458 \\
\hline dum_trade_figt-2 & -0.007275 & 0.002591 & -2.807205 \\
\hline dum trade_fig t. $_{-5}$ & -0.005650 & 0.002707 & -2.087466 \\
\hline dum_reserv_figt.3 & 0.006981 & 0.002761 & 2.528208 \\
\hline$\Delta \ln \left(\mathrm{R} 150_{\mathrm{t}+3}\right)$ & -0.105799 & 0.041692 & -2.537626 \\
\hline$\Delta \ln \left(R 150_{t-3}\right)$ & -0.142182 & 0.044427 & -3.200321 \\
\hline foreign_eff. & $-2.33 \mathrm{E}-06$ & $9.91 \mathrm{E}-07$ & -2.351186 \\
\hline$\Delta \ln \left(r_{\text {repo }}+1-1\right)$ & 0.068055 & 0.024328 & 2.797391 \\
\hline$\Delta \ln \left(\right.$ repo $\left._{1.3}\right)$ & 0.096777 & 0.024203 & 3.998562 \\
\hline$\Delta \ln \left(\right.$ mon_assis $\left._{1+2}\right)$ & 0.007786 & 0.003861 & 2.016721 \\
\hline
\end{tabular}

Sample period: 05/01/1998 -15/12/1998

Included observations: 226 after adjusting endpoints 


$\begin{array}{lllll}\mathrm{R}^{2} & 0.687176 & \eta_{1}(2) & 13.67068 & {[0.001075]} \\ \overline{\mathrm{R}}^{2} & 0.661609 & \eta_{2}(1) & 0.043494 & {[0.834798]} \\ \mathrm{F}(18,208) & 26.87712 & \eta_{3}(32) & 61.68 & {[0.001244]} \\ \text { s.e. } & 0.007921 & \eta_{4}(2) & 0.043651 & {[0.957296]} \\ & & \eta_{5}(36) & 34.392 & {[0.545000]} \\ & & \eta_{6}(2) & 1.771553 & {[0.412394]}\end{array}$

$\eta_{1}$ denotes the Jarque-Bera test for the normality assumption; $\eta_{2}$ and $\eta_{3}$ denote the ARCH LM and the White tests respectively for the homoscedasticity assumption; $\eta_{4}$ and $\eta_{5}$ denote test statistics of the assumption of serial correlation - the Breusch-Godfrey LM test and the Lung Box Q test; while $\eta_{6}$ denotes the Ramsey RESET test statistic for misspecification. All $\eta_{i}$ (d.f.) are in $\chi^{2}$ form, with figures in round brackets denoting degrees of freedom. The figures in square brackets denote the probability values.

Table 3 Cointegration correction: Dependent variable: $\ln \left(\mathbf{R} 150_{t}\right)$

\begin{tabular}{|c|c|c|c|}
\hline & Coefficient & s.e. & t-ratio \\
\hline $\ln ($ rand_dollar $)$ & 0.895262 & 0.014471 & 61.86594 \\
\hline $\ln \left(\right.$ jseover $\left._{1}\right)$ & -0.320155 & 0.017992 & -17.79430 \\
\hline constant & 2.642065 & 0.285303 & 9.260568 \\
\hline
\end{tabular}

Figure 2 R150 Yield rate, actual and predicted, 1998

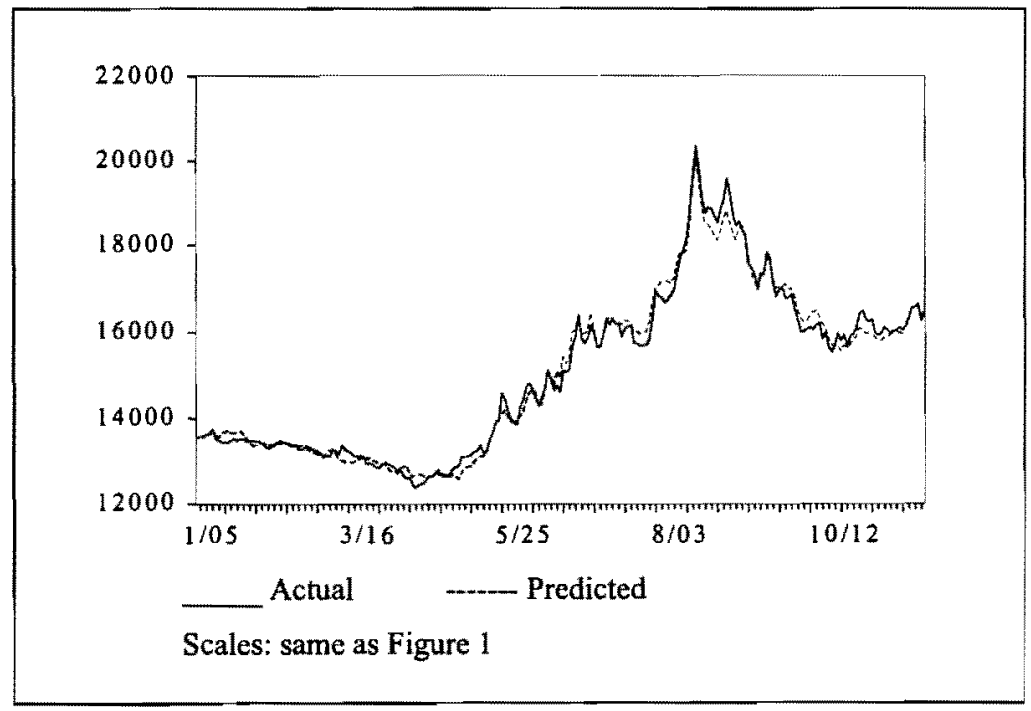




\subsection{Dynamic simulation: response characteristics of the model}

An initial dynamic simulation (without applying any shocks) was carried out as an indication of the goodness of fit of the model. The response characteristics of the model were evaluated by subsequently subjecting the model to sensitivity testing by changing (shocking) all explanatory variables (one at a time). This was done by increasing them by 10 per cent. For a model to be stable and robust, shocks applied to it should result in consistent long-run multiplier effects. A consistent long-run multiplier effect means that the difference between the shocked simulated value and the simulated value without a shock must ideally result in approximately 10 per cent of the original coefficient of the shocked variable (i.e. the multiplier effect). A shock in short-term explanatory variables should cause an initial movement away from the long-run equilibrium growth path, but eventually the model should converge on the original equilibrium growth path.

All explanatory variables were shocked by 10 per cent. In all cases the dependent variable converged on a new equilibrium at a higher level, equal to 10 per cent of the estimated coefficient of the shocked long-run explanatory variable, or it converged on the original equilibrium growth path in the case of shocked short-run explanatory variables.

Results of the adjustment process towards either a new long-run equilibrium (in accordance with the elasticities of the respective cointegration relationships) or the baseline equilibrium (in the case of short-run explanatory variables) are shown in figures 2 and 3 . Vertical axes measure the difference between the outcome of baseline estimation and the estimation subjected to the exogenous shock, as a percentage of the level of the dependent variable. The speed of adjustment in the respective cases is apparent from the graphs. In all instances the adjustment process is completed within the sample range. 
Figure 3 Response characteristics of the error correction model (time scales same as figures $1 \& 2$ )

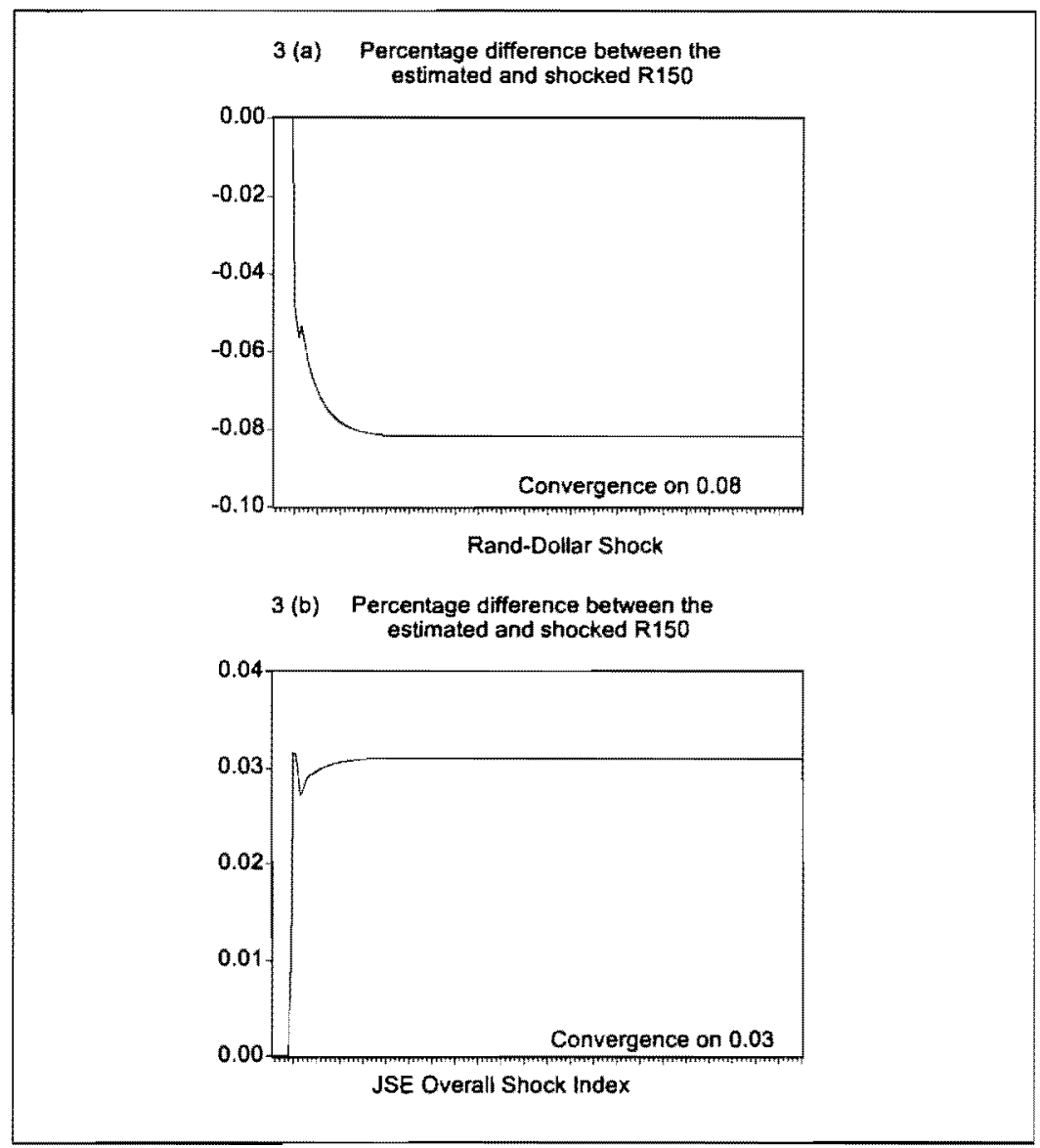

\section{ECONOMIC EVALUATION OF RESULTS}

From the long-run equilibrium relationship it appears that changes in the rand/dollar exchange rate and the Johannesburg Stock Exchange (JSE) share price index dominate long-run movements in the R150-bond rate. Speculation against the rand and selling of equities on the JSE by foreigners led to a sharp increase by almost 800 points in capital market rates during the East Asian and Russian crises (Figure 1). The consequent transmission effect on short-term 
interest rates caused the banks to increase their prime rate by more than 7.0 per cent to 25 per cent during the third quarter of 1998 (QB, December 1998: S-28). The significant high value of the intercept (constant) of 2.64 could reflect the movements in market sentiment, the risk to invest in South Africa given the current economic structure.

The dynamic results of the ECM-model indicate that foreign market movements were mostly attributed to the volatile short-run changes in capital market rates. Changes in the Dow Jones share index, the rand/pound exchange rate and the US long bond rate movements on a daily basis, contributed to the erratic changes in South African bond rates. The net purchases/sales of stock by foreigners were also a significant cause of short-run fluctuations in the R150rate. Changes in international sentiment towards emerging market economies in general, were reflected in the negative movements of these indicators. The rand/dollar exchange rate depreciated by more than 23 per cent, as foreigners sold R150 bonds to the value of more than $\$ 2$ billion during the third quarter of 1998 (www.sharenet.co.za, Appendix 3).

The announced key indicators of the South African economy on a monthly basis served as dummy variables. Portfolio managers reacted to these data before and after their announcement. Foreign trade figures had the biggest effect on the R150-rate with a two-day and a five-day lag. Negative trade figures were interpreted by portfolio managers as a weakening of the current account on the balance of payments, which would lead to an expected further depreciation of the currency. As a result, bonds were sold two to five days after the announcement. The same reaction, lagging three days, also occurred after the announcement of South Africa's foreign reserve figures.

International economic and political events, as a dummy variable, also showed a significant effect on the dynamic movement in the R150-rate. News of East Asian and Russian financial market uncertainty immediately affected the South African bond market negatively. During such periods, net selling of bonds by foreigners and the accelerated depreciation of the rand exchange rate were common phenomena.

A significant relationship between daily money market movements and the R150-rate was found. Periods of a liquidity shortage in the money market led to an increase in the banks' daily demand for cash assistance from the Reserve bank (the money market shortage). The result was an increase in the Reserve Bank's repo rate (assistance rate). This upward pressure on short-term interest rates also led to domestic and foreign selling of bonds on the capital market. 
Lastly, the market makers also played a significant role in the erratic movements of bond rates. Buyers and sellers acted on the market according to the $t+3$ day method of settling accounts. Buyers and sellers thus cleared their positions within three days of each transaction. These speculative reactions influenced the movements in bond rates significantly.

\section{THE EFFECT ON MONETARY POLICY}

The results of the long-run equilibrium growth path of long-term interest rates and the error correction model, show that capital market rates in South Africa reacted mostly to exchange rate changes, foreign market sentiment and foreignrelated economic indicators (trade and reserve figures) during international financial turmoil. Short-term interest rates followed rather than led long-term interest rates in the long run. However, in the short run, changes in money market rates affected the dynamic behavior of the R150-rate. In this regard, the challenge to monetary policy in an emerging country like South Africa, is to stabilize the exchange rate. Exchange rate stability seems to have become the primary objective of monetary and interest rate policy in South Africa, with domestic price stability taking second place.

Evidence for South Africa shows that a lower inflation rate during 1998 was not reached due to lower growth of the M3 money supply or the extension of less credit to the public by the monetary banking sector. Both these aggregates recorded average growth of more than 15 per cent during 1998 (QB, June 1998: S22-23). Rather, the lower inflation rate (which fell from 9.9 per cent in February to 5.5 per cent in July) was due to the stable exchange rate and subsequent decrease in import prices and interest rates. During the East Asian crisis from April to October, the rand depreciated from R5.96/\$ to R6.70/\$ (www.sharenet.co.za). The accompanying sharp increase in both long-run and short-run interest rates led to a sharp increase of the inflation rate to 9.4 per cent in 1998 (QB, June 1998: S148). The evidence therefore shows that price stability follows exchange rate stability, not the other way around.

\section{CONCLUSION}

This paper attempted to determine a long-run capital market rate function for South Africa during a period of international financial uncertainty. The model first used a long-run cointegration technique, applying the Engle and Yoo threestep procedure, with an extension of the Engle-Granger two-step procedure. At the second stage, an error correction model (ECM) was constructed to estimate the short-run dynamic adjustment process to long-run equilibrium. All variables 
in the ECM were stationary, according to the assumptions of classical regression analysis. The coefficients and $t$-statistics were adjusted to be closer to their true values, after which a correction was made to the parameter estimates of the first stage static regression was made. The third stage consisted of a further regression of the conditioning variable from the static regression, multiplied by minus the error correction parameter, regressed on the errors from the secondstage error correction model.

The estimation results for the R150-bond were listed in terms of the long-run relationship - the cointegration equation - followed by the ECM together with results from diagnostic tests performed on the ECM. From this a dynamic simulation was done by shocking the explanatory variables by 10 per cent. In all cases the dependant variable converged on a new equilibrium at a higher level, equal to 10 per cent of the estimated coefficient of the shocked long-run explanatory variable. This means that the dependent variable converged on the original equilibrium growth path in cases where short-run explanatory variables were shocked.

Evaluation of the results shows that the rand/dollar exchange rate and the Johannesburg Stock Exchange all share index movements, were responsible for more than 90 per cent of the long-run movement in the $\mathrm{R} 150$ bond rate. The short-run dynamics of the model indicate that foreign market sentiment, foreign buying and selling of bonds, movements in the Dow Jones all share index and US long bond rate changes determined the erratic movements of R150 around the long-run growth equilibrium path. The monthly key economic indicator announcements like trade and foreign reserve figures and growth in the money supply (and credit extension to the public), also played a significant role in the short-run dynamic movement of capital market rates. Lastly, money market indicators, namely the repo rate and daily cash assistance to the banks by the Reserve Bank, also influenced the short-run movement of the R150 bond rate.

It therefore follows, that whereas capital market rates were mostly determined by domestic demand and supply for shares and bonds prior to the 1994 election, global financial markets and international market sentiment started to dominate movements of the South African capital market rates after 1994. This structural change has important consequences for economic policy in general, and South African monetary policy in particular. 


\section{APPENDIX 1}

\section{List of variables}

\begin{tabular}{|c|c|}
\hline Series & Description \\
\hline $\mathrm{R} 150_{\mathrm{f}}$ & R1 50 yield rate \\
\hline rand dollar & rand/dollar exchange rate \\
\hline dow $_{\mathrm{t}}$ & $\begin{array}{l}\text { Dow Jones Stock Exchange index : overall } \\
\text { index (US) }\end{array}$ \\
\hline jseover & $\begin{array}{l}\text { Johannesburg Stock Exchange : overall index } \\
\text { (South Africa) }\end{array}$ \\
\hline mon assis a $_{t}$ & cash assistance towards to the money market \\
\hline pound $_{t}$ & rand/pound exchange rate \\
\hline repor & $\begin{array}{l}\text { repo rate (South African short-run interest } \\
\text { rate) }\end{array}$ \\
\hline ustbond $30_{t}$ & US 30 year bond rate \\
\hline foreign_eff & $\begin{array}{l}\text { net purchase of South African R150 bonds by } \\
\text { foreigners }\end{array}$ \\
\hline$\overline{\text { dum_foreign }}$ & $\begin{array}{l}\text { dummy: international economic and political } \\
\text { events }\end{array}$ \\
\hline dum_trade_figa & $\begin{array}{l}\text { dummy: announcement of monthly } \\
\text { merchandise trade figures }\end{array}$ \\
\hline dum_reserv_figt & $\begin{array}{l}\text { dummy: announcement of monthly level of } \\
\text { foreign reserves }\end{array}$ \\
\hline
\end{tabular}




\section{APPENDIX 2 \\ Order of integration}

The augmented Dickey-Fuller test was employed in order to test whether the data series are stationary. The testing strategy followed is as suggested by Dolado et al. (1990), and as applied also by Strum and De Haan (1995).

Dickey and Fuller (1981) consider the problem of testing the null hypothesis on non-stationarity versus stationarity, suggesting ordinary least squares estimation of $\Delta Y_{t}=\eta_{0}+\eta_{1}$ Trend $+\eta_{2} Y_{t-1}+\sum_{i=1}^{m} \eta_{2+1} Y_{t-1}+\varepsilon_{1} \ldots$ (1) where $Y_{t}$ is the series being tested, $m$ is the number of lags in the testing equation and $\varepsilon_{\mathrm{t}}$ is the residual.

The test is implemented through the usual $\mathbf{t}$-statistic of $\hat{\eta}_{2}$, denoted as $\tau_{\tau}$. Under the null hypothesis $\tau_{\tau}$ will not follow the standard $t$-distribution; adjusted values as computed by McKinnon (1990) are used for evaluation. If $\tau_{\tau}$ is significant, the null of non-stationarity is rejected and the series are stationary. In that case there is no need to go futher.

However, if $\tau_{\tau}$ is insignificant, the joint null hypothesis that $0_{1}=0_{2}=0$ using the F-statistic denoted as $\Phi_{3}$ is tested. The relevant critical values from Dickey and Fuller are used. If $\Phi_{3}$ is significant, test again for a unit root, now using the critical values of the standard $t$-distribution.

If the trend is not significant in the maintained model, the next step would be to estimate equation (1) without a trend $\left(\eta_{1} \equiv 0\right)$. Again test for the unit root, now denoting the t-statistic of $\hat{\eta}_{2}$ as $\tau_{\mu}$ and using the relevant critical values from McKinnon. If the null hypotheses is rejected, again there is no need to go further.

If it is not rejected, the joint null hypothesis $\eta_{0}=\eta_{2}=0$ with use of the F-statistic, denoted as $\Phi_{1}$, is tested, employing the critical values reported by Dickey and Fuller. Again, if it is significant, test for a unit root using the standardised normal distribution.

If not, remove the constant from the testing equation as well $\left(\eta_{0} \equiv \eta_{2} \equiv 0\right)$. The new statistic is called $\tau$. Again McKinnon reports relevant critical values for this t-statistic. The last step is to examine whether the null hypotheses is rejected or not, i.e. whether the series are stationary or not. 
The number of lags used in the estimated equations were determined in a similar way as Perron (1989). Perron suggested starting with eight lags. If the last lag is insignificant at a 10 per cent level (using the standard normal distribution), then it is omitted. Now seven lags are included. Again it is tested whether the last lag is significant (or there are no lags left, in which case the test is called the Dickey-Fuller (DF) test). This large significance level is taken because, as Perron (1989: 1384) pointed out, "..including too many regressors of lagged first-differences does not affect the size of the test but only decreases its power. Including too few lags may have a substantial effect on the size of the test". Furthermore, Molinas (1986) noticed that "...a rather large number of lags has to be taken in the ADF test in order to capture the essential dynamics of the residuals".

Tables $\mathrm{A} 1$ and $\mathrm{A} 2$ report the outcomes of the $\mathrm{ADF}$ tests for all relevant data series employed in the estimations. The series tested are given in the first column. The second column reports whether a trend and a constant (Trend), only a constant (Constant), or neither (None) is included. In the third column, the number of lags recorded are reported. The next column shows the ADF tstatistic, called $\tau_{\tau}$ when a trend and constant are included, $\tau_{\mu}$ when only a constant is included, and $\tau$ when neither occurs. The last column reports the Fstatistic, $\Phi_{3}\left(\Phi_{1}\right)$, testing whether the trend (constant) is significant under the null hypothesis of no unit root.

According to table Al there are 5 variables that seem to be stationary in levels. However, the test results are not conclusive for 4 of the variables and much doubt exits whether these variables are indeed stationary in their levels. By simply looking at data plots of of the natural logarithm forms of the variables In_dow, In_jseover, In_mon_assis and In_ustbond30, it is obvious that these series cannot be stationary in levels. Table A2 indicates that all variables, except foreign_eff, are indeed integrated of order 1. Due to the nature of construction of the dummy variables, they are all integrated of order 0 and are therefore all stationary in levels. 
Table A1 Augmented Dickey-Fuller tests for non-stationarity, levels, 05/01/98 - 11/12/98

\begin{tabular}{|c|c|c|c|c|}
\hline Series & Model & Lags & $\tau_{\tau}, \tau_{\mu}, \tau$ & $\Phi_{3}, \Phi_{1}$ \\
\hline \multirow[t]{3}{*}{ ln_dollar_rand } & Trend & 5 & -1.46 & 2.58 \\
\hline & Constant & 5 & -1.16 & 2.87 \\
\hline & None & 5 & 0.78 & \\
\hline \multirow{3}{*}{ ln_dow } & Trend & 7 & -2.27 & $1.83^{*}$ \\
\hline & Constant & 7 & -2.35 & $2.07 * *$ \\
\hline & None & 7 & 0.53 & \\
\hline \multirow[t]{3}{*}{ In_jseovert } & Trend & 1 & -1.76 & $7.34^{*}$ \\
\hline & Constant & 1 & -0.67 & 8.63 \\
\hline & None & 1 & -0.75 & \\
\hline \multirow[t]{2}{*}{ In_mon_assis } & Trend & 7 & -3.13 & $3.82^{* *}$ \\
\hline & $\begin{array}{l}\text { Constant } \\
\text { None }\end{array}$ & 7 & $-3.15^{*}$ & $4.32 * *$ \\
\hline \multirow[t]{3}{*}{ In_pound } & Trend & 7 & -1.01 & 3.62 \\
\hline & Constant & 7 & -1.09 & 4.07 \\
\hline & None & 7 & 0.97 & \\
\hline \multirow[t]{3}{*}{ ln_R150 } & Trend & 3 & -1.24 & 3.40 \\
\hline & Constant & 3 & -0.59 & 3.94 \\
\hline & None & 6 & 0.65 & \\
\hline \multirow[t]{3}{*}{ In_repo } & Trend & 5 & -1.23 & 15.53 \\
\hline & Constant & 5 & -1.11 & 18.12 \\
\hline & None & 5 & 0.46 & \\
\hline \multirow[t]{3}{*}{ ln_ustbond $30_{t}$} & Trend & 4 & -2.63 & $3.21 * *$ \\
\hline & Constant & 4 & -0.25 & 2.11 \\
\hline & None & 4 & -1.09 & \\
\hline foreign_eff & $\begin{array}{l}\text { Trend } \\
\text { Constant } \\
\text { None }\end{array}$ & 8 & $-3.87^{*}$ & $17.71^{* *}$ \\
\hline
\end{tabular}

${ }^{*}(* *)$ Significant at a $5(1)$ per cent level.

a At a 5(1) per cent significance level the McKinnon critical values are 3.43(-3.99) when a trend and a constant are included $\left(\tau_{\tau}\right)$, and $2.88(-3.46)$ when only a constant is included $\left(\tau_{\mu}\right)$, and $-1.95(-2.58)$ when neither is included $(\tau)$. The standard normal critical value is $-1.645(-$ 2.33).

b At a S(1) per cent significance level the Dickey-Fuller critical values (for 250 observations) are $6.34(8.43)$ when a trend and a constant are included $\left(\Phi_{3}\right)$, and $4.63(6.52)$ when only a constant is included $\left(\Phi_{1}\right)$. 
Table A2 Augmented Dickey-Fuller tests for non-stationarity, first differenced, 05/01/98 - 11/12/98

\begin{tabular}{|c|c|c|c|c|}
\hline Series & Model & Lags & $\tau_{\tau}, \tau_{\mu}, \tau$ & $\Phi_{3}, \Phi_{1}$ \\
\hline$\Delta \mathrm{ln}$ _dollar_rand & $\begin{array}{l}\text { Trend } \\
\text { Constant } \\
\text { None } \\
\end{array}$ & 4 & $-5.29 * *$ & $31.72 * *$ \\
\hline$\Delta \ln \_$dow & $\begin{array}{l}\text { Trend } \\
\text { Constant } \\
\text { None } \\
\end{array}$ & 6 & $-5.16^{* *}$ & $24.23^{* *}$ \\
\hline$\Delta \ln _{\text {joseover }}$ & $\begin{array}{l}\text { Trend } \\
\text { Constant } \\
\text { None }\end{array}$ & 0 & $-11.33^{* *}$ & $64.15^{* *}$ \\
\hline$\Delta \ln _{\text {n_mon_assis }}$ & $\begin{array}{l}\text { Trend } \\
\text { Constant } \\
\text { None } \\
\end{array}$ & 6 & $-4.62 * *$ & $43.32^{* * *}$ \\
\hline$\Delta \ln \_$pound & $\begin{array}{l}\text { Trend } \\
\text { Constant } \\
\text { None } \\
\end{array}$ & 6 & $-6.12 * *$ & $32.77 * *$ \\
\hline$\Delta \ln \_R 150_{t}$ & $\begin{array}{l}\text { Trend } \\
\text { Constant } \\
\text { None }\end{array}$ & 5 & $-5.76 * *$ & $19.85^{* *}$ \\
\hline$\Delta$ ln_repo $_{\mathrm{t}}$ & $\begin{array}{l}\text { Trend } \\
\text { Constant } \\
\text { None }\end{array}$ & 4 & $-5.50 * *$ & $48.50^{* *}$ \\
\hline$\Delta \mathrm{ln}$ _ustbond $30_{\mathrm{t}}$ & $\begin{array}{l}\text { Trend } \\
\text { Constant } \\
\text { None }\end{array}$ & 8 & $-4.89^{* *}$ & $21.67^{* *}$ \\
\hline
\end{tabular}

${ }^{*}\left({ }^{* *}\right)$ Significant at a $5(1)$ per cent level.

a At a 5(1) per cent significance level the McKinnon critical values are $3.43(-3.99)$ when a trend and a constant are included $\left(\tau_{t}\right)$, and $-2.88(-3.46)$ when only a constant is included $(\tau)$, and $-1.95(-2.58)$ when neither is included $(\tau)$. The standard normal critical value is $-1,645(-$ 2.33).

b At a 5(1) per cent significance level the Dickey-Fuller critical values (for 250 observations) are $6.34(8.43)$ when a trend and a constant are included $\left(\Phi_{3}\right)$, and $4.63(6.52)$ when only a constant is included $\left(\Phi_{1}\right)$. 


\section{APPENDIX 3 Graphical representation of data}

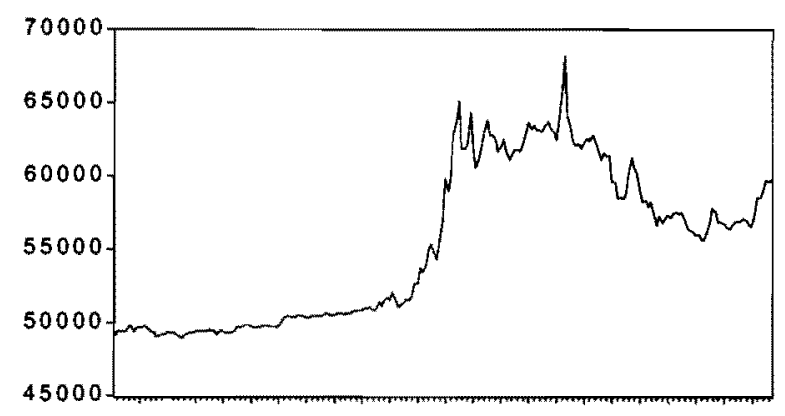

RAND/DOLLAR EXCHANGE RATE
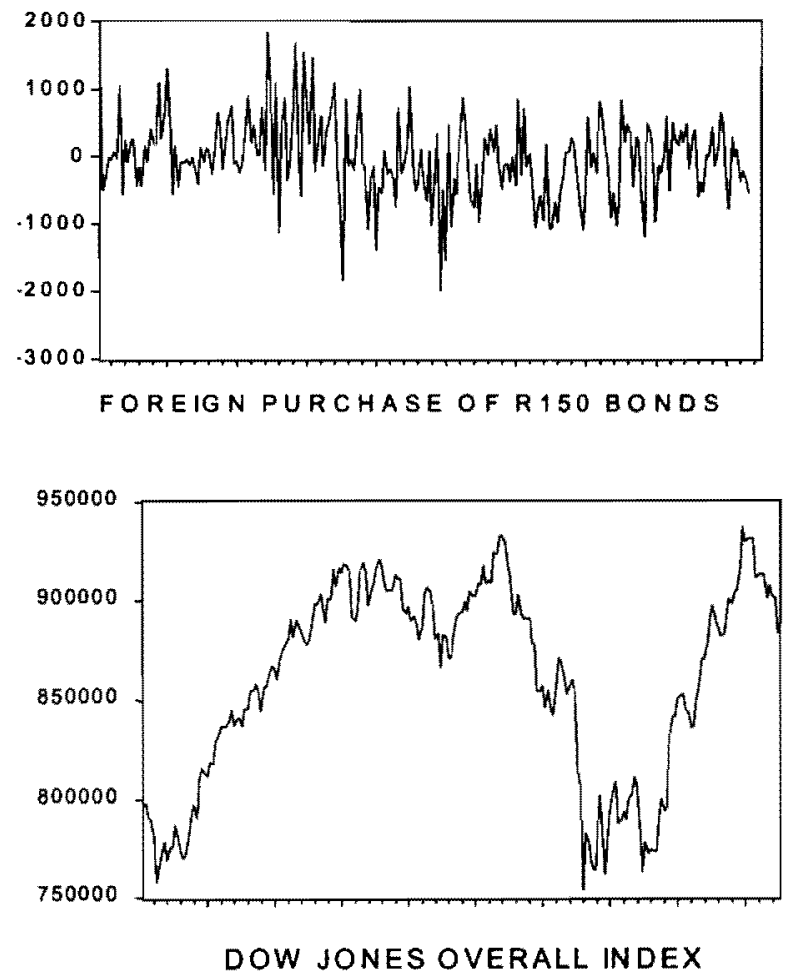


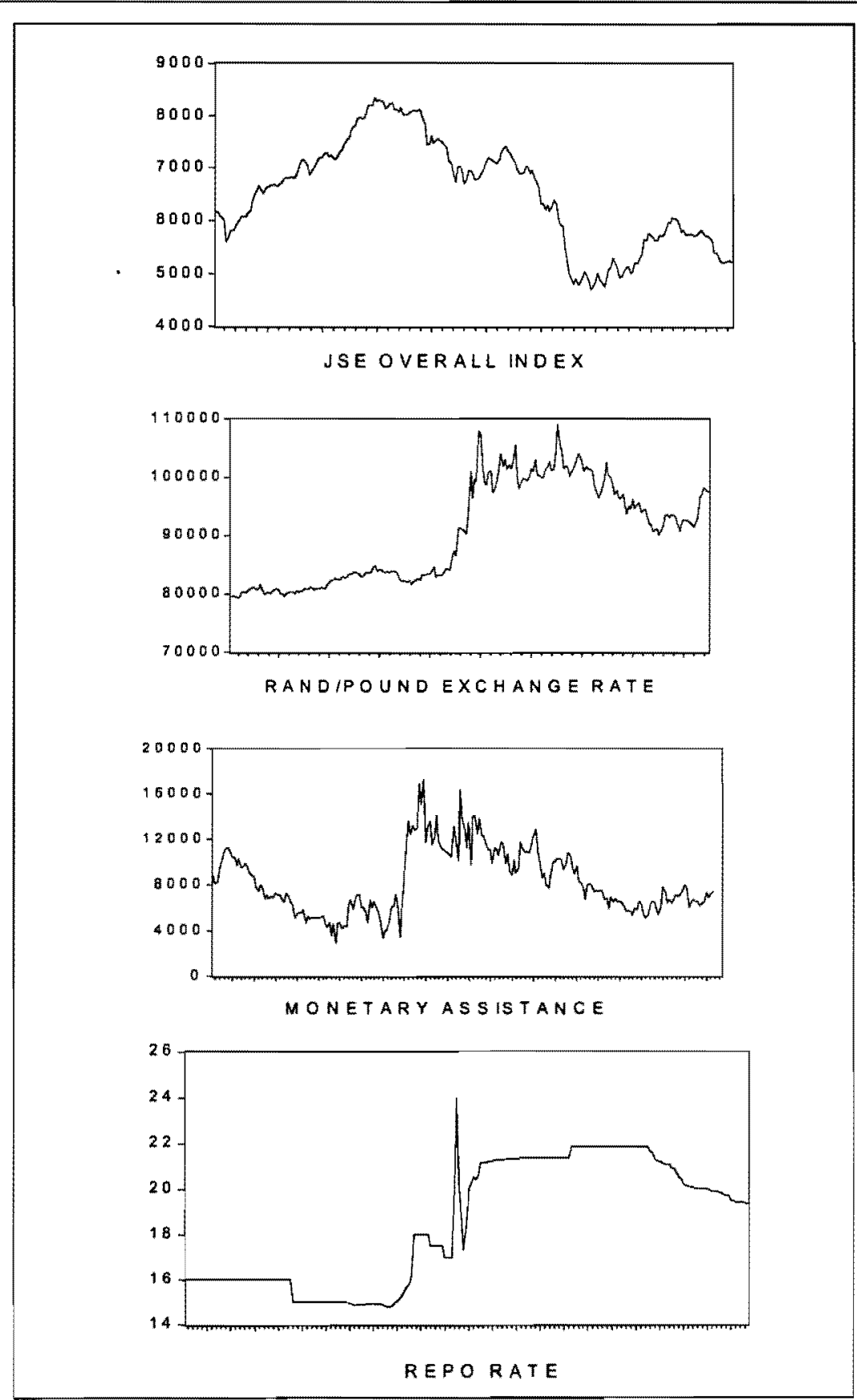




\section{ENDNOTES}

1 South African Reserve Bank Database SAFEX Database

Statistics South Africa Database South African Department of Finance South African Excise and Duties Sharenet Database Reuters Database www.resbank.co.za

www.safex.co.za www.statssa.gov.za www.finance.gov.za www.sas.gov.za www.sharenet.co.za

2 See Appendix 1 for variable list.

3 This test consists of a unit root test on the residuals of the cointegration equation. It is also referred to as the (cointegration regression) augmented Dickey-Fuller tests. To make a clear distinction between this test and the augmented Dickey-Fuller test on stationarity, Davidson and McKinnon (1993) are followed in naming this test the augmented Engle-Granger test. The difference between these tests result from the critical values which are used. Critical values for the relevant response surfaces can be found in McKinnon (1991). The response surface for any number of regressors, excluding any constant and trend component, $1 \leq n \leq 6$, can be calculated as $C(p)=\Phi_{\infty}+\Phi_{1} T^{-1}+\Phi_{2} T^{-2}$ The 10 per cent critical value in this case, with $\mathrm{n}=2$ and $\mathrm{p}$ (sample size) $=237$ is -3.063 .

\section{REFERENCES}

1 BANERJEE, A., DOLADO, J., GALBRAITH, J.W. and HENDRY, D.F. (1996) Co-Integration, Error-correction, and the Econometric Analysis of Non-Stationary Data, Oxford University Press.

2 CHAREMZA, W.W. \& DEADMAN, D.F. (1997) New Directions in Econometric Practice, Edward Elgar.

3 ENGLE, R.F. and GRANGER, C.W.J. (1987) "Co-integration and Error Corrections Representation, Estimation and Testing", Econometrica, 55: 987-1007.

4 ENGLE, R.F. and YOO, S. (1989) A Survey of Cointegration, mimeo, University of California, San Diego.

5 FOURIE, L.J., FALKENA, H.B. and KOK, W.J. (1992) Fundamentals of the South African Financial System, Southern Book Publishers.

6 HARRIS,R.I.D. (1995) Using Co-integration in Econometric Modelling, Prentice Hall.

7 MCKINNON, J.G. (1990) Critical Values for Cointegration Tests, Department of Economics Discussion Paper No 90-4, University of California, San Diego. 
8 MCKINNON, J.G. (1991) "Critical Values for Co-Integration Tests", in R.F. Engle and C.W.J. Granger (eds.) Long-run Economic Relationships, Oxford University Press: 267-76.

9 QB: South African Reserve Bank Quarterly Bulletin, Various issues. 